\title{
PENGARUH RENDAM KAKI DENGAN AIR GARAM HANGAT TERHADAP PENINGKATAN KUALITAS TIDUR PADA LANSIA DI PANTI JOMPO
}

\author{
Irfan Harefa*, Septi Cahyani Laowo, Diyan Marsella Sirait, Delfiana Zamili, Vania Almira, \\ Karmila Br Kaban \\ Fakultas Keperawatan dan kebidanan,UniversitasPrimaIndonesia, Jl. Danau Singkarak, Gg. Madrasah, \\ Sei Agul, Kec. Medan Barat, Kota Medan, Sumatera Utara 20117, Indonesia \\ *irfanharefa2011@gmail.com (+6282390220298)
}

\begin{abstract}
ABSTRAK
Kualitas tidur merupakan kebutuhan tidur seseorang dalam mencapai tingkat kepuasan terhadap tidur. Gangguan tidur sering terjadi pada umur >60 tahun, Seiring pertambahan umur, maka dalam tubuh akan mengalami penurunan dan perubahan terutama pada fungsi org an dan sistem tubuh. Maka hidroterapi kaki dilakukan, merendam kaki dengan air garam hangat memiliki efek meningkatkan sirkulasi darah dan menumbuhkan rasa rileks serta mengurangi stress. Tujuan penelitian ini dilakukan untuk menentukan adanya pengaruh kuliatas tidur pada lanjut usia. Penelitian ini menggunakan metode pre-eksperimen maka peneliti memakai program one group pre-test dan post-test design. Jumlah responden 20 orang. Teknik pengumpulan data yaitu dengan memakai lembar kuesioner Pittsburgh Sleep Quality Index (PSQI) disampaikan peneliti dengan metode interview-based terdiri atas 19 pertanyaan. Hasil penelitian membuktikan terdapat pengaruh meningkatnya kualitas tidur pada lansia nilai $\mathrm{p}$ ( $\mathrm{p}$-value $)=0,000(\mathrm{p}<0,05)$ setelah melakukan rendam kaki dengan air garam hangat. Kesimpulan dalam penelitian ini adanya pengaruh kualitas tidur pada lansia yang menjalani terapi rendam kaki dengan air garam hangat di Panti Jompo Yayasan Guna Budi Bakti Medan 2021.
\end{abstract}

Kata kunci: kualitas tidur; lansia; rendam kaki dengan air garam hangat

\section{THE EFFECT OF SOAKING FEET USING WARM SALT WATER TO THE IMPROVEMENT OF SLEEP QUALITY IN THE ELDERLY AT THE PANTI JOMPO}

\begin{abstract}
Sleep quality is a person's sleep needs in achieving a level of satisfaction with sleep.Sleep disturbances often occur at age $>60$ years, with increasing age there will be changes in the function of organs and body system. Then performed foot hydrotherapy, soaking feet using warm salt water has the effect of improving blood circulation and fostering a sense of relaxation and reducing stress.The purpose of this study was to determine the influence of sleep quality in the elderly.This study used a pre-experimental method, the researchers used a one group pre-test and post-test design program.The number of respondents was 20 people. The data collection technique was using the Pittsburgh Sleep Quality Index (PSQI) questionnaire, which was delivered by the researcher using an interview-based method consisting of 19 questions.The results of the study prove that there is an effect of increasing sleep quality in the elderly(pvalue $)=0.000(p<0.05)$ after doing soaking feet using warm salt water.The conclusion in this study was the effect of sleep quality on the elderly who underwent foot soak therapy with warm salt water at the Panti Jompo Yayasan Guna Budi Bakti Medan 2021.
\end{abstract}

Keywords: elderly; sleep quality; soaking feet using warm salt wate 


\section{PENDAHULUAN}

Lanjut usia (Lansia) didefinisikan sebagaitahap lanjutan dari suatu proses kehidupan yang dikenal dengan adanya perubahan dan penurunan kemampuan kualitas tubuh dalam beradaptasi dengan stress lingkungan. Klasifikasi lansia yang telah dijadikan patokan untuk lansia itu sendiri berbeda-beda. (Firdaus, dkk. 2018). Menurut data kementrian kesehatan RI (2016), usia harapan hidup (UHH) terjadi kenaikan mulai 68,6 (2004) menjadi 72 tahun (2015) ini diperkirakan akan terus mengalami kenaikan, dan akan berdampak pada lonjakan jumlah penduduk lansia (Ratnawati, 2017).

Secara mendunia komunitas lansia akan terus meningkat dan di prediksi mengalami kenaikan khususnya di negara-negara berkembang pada periode mendatang. Di tahun 1970 khususnya di negara indonesia terjadi kenaikan yang cukup besar dari 5,30 juta jiwa (sekitar $4,48 \%$ ) bertambah 18,10 juta jiwa (2010), dan di tahun 2014 berjumlah 20,7 juta (sekitar 8,2\%), sedangkan 2020 menjadi 27 juta jiwa. (Kemenkes, 2013; Kemenkes,2016).

Hasil proyeksi penduduk di tahun 20102035, Indonesia merupakan suatu negara yang akan mengalami peningkatan drastisjumlah populasi lansia. Periode lansia (ageing) akan di alami indonesia di mana rentang umur 0-14 tahun dan 15-49 mengalami penurunan 2010-2035 sedangkan rentang umur (50-64 tahun dan 65) akan semakin meningkat di tahun 2010-2035. Di wilayah Asia khususnya di indonesia komunitas lansia di perkirakan akan mengalami peningkatan lebih besar setelah $2050 \quad$ (Kemenkes, 2013; Kemenkes,2016).
Seiring bertambahnya umur manusia, pastinyaakan mengalami proses penuaan yang di sertai dengan berbagai masalah kesehatan yang berdampak pada alterasi terutama pada fisik, sosial, perasaan dan kognitif. (Prananto,2016). Pada tahapan lanjut usia yang mengalami penurunan di tandai dengan fungsi organ tubuh dan kondisi fisik yang menurun merupakan proses alami. Pada proses ini lansia akan mudah mengalami gangguan pada tidurnya. (Daniel \& Laila, 2019).

Proses penuaan dapat memicu alterasi tidur dan istrahat lansia serta membuat lansia lebih mudah mengalami gangguan tidur. Seiring bertambahnya usia seseorang akan mengalami penurunan kapasitas organ dan kondisi mental dan psikososial misalnya stres, depresi, cemas, dan kurangnya percaya diri. (Erfrandau, dkk, 2017). Gangguan tidur adalah masalah bagi lansia karena berdampak dengan kualitas hidup, kenikmatan dan kebahagiaan bagi para lansia. Lanjut usia dan orang dewasa pola tidurnya sangatlah berbeda, untuk itu lansia perlu mendapatkan perhatian lebih dari para petugas kesehatan. Karena struktur tidur lanjut usia berbeda maka lansia kurang merasakan kenikmatan tidur pulas dari pada orang dewasa. (Syaharani, 2020).

Permasalahan yang dapat dilakukan dalam masalah gangguan tidur cara penanganannya ada dua yaitu farmakologi dan non farmakologi. Strategi non-farmakologis adalah pilihan lain yang lebih aman, khususnya dengan menyerap air garam hangat untuk kaki. Merendam kaki dengan air garam hangat merupakan reaksi pelonggaran yang dapat meningkatkan kualitas istirahat serta mengurangi aktivitas saraf simpatis, meningkatkan saraf parasimpatis bekerja aktif dan 
lebih berperan. (Potter \& Perry, 2010).

Terapi merendam kaki dapat meningkatkan peredaran darah dengan cara memperluas pembuluh darah serta mengirimkan oksigen banyak ke jaringan-jaringan tubuh yang telah mengenyami peradangan. Terapi peredaran darah dapat menlancarkan peredaran getah bening serta mengangkat racun dalam tubuhseorang yang mengidap berbagai penyakit yaitu insomnia kelelahan, stres, radang sendi, sakit punggung nyeri otot, rematik, keram dan kaku. (Wulandari et al, 2016).

Merendam kaki dengan air hangat yang ditambah garam dapat memperlancar efek relaksasi bagi tubuh. (Nuyridayanti, 2017).Toksin dari tubuh akan terserat oleh panas dari garam membuat peredaran darah menjadi lancar. (Dewi,dkk, 2020). Tubuh menjadi rileks dari pengaruh air hangat serta menghilangkan rasa kekakuan di otot, rasa pegal-pegal dan membuat tidur lebih nyenyak. (Daniel\&Laila, 2019).

Hasil survei diawal dilaksanakan peneliti di Panti Jompo Yayasan Guna Budi Bakti pada bulan oktober terdapat 40 pasien lansia yang mengalami kesulitan dalam pola istirahat atau tidur. Penelitian bertujuan untuk mengetahui pengaruh rendam kaki dengan air garam hangat terhadap peningkatan kualitas tidur pada lansia.

\section{METODE}

Jenis penelitian dilaksanakan ialah preeksperimen yang menerapkan program one group pre-test serta post-test design yang mana observasi di lakukan pada sabjek sebelum intervensi dilakukan serta kembali di observasi setelah intervensi dilakukan. Penelitian ini menggunakan populasi ialah lansia yang menderita masalah penurunan kualitas tidur dengan jumlah 20 responden. terhitung dari bulan Januari 2020. Berdasarkan banyaknya populasi diambil kurang dari 30 orang maka teknik pengumpulan sampel adalah Teknik Total Sampling, yang mana keseluruhan populasi dibuat menjadi sampel.

Teknik pengumpulan data pada penelitian yang diterapkan adalah memakai lembaran kuesioner Pittsburgh Sleep Quality Index (PSQI) disampaikan dengan metode interviewbased terdiri atas 19 pertanyaan. Metode analisa data ialah analisa univariat sertaanalisa bivariat. Pada penelitian ini Analisa univariat menjelaskan frekuensi distribusi variabel karakteristik responden adalah, umur, pendidikan, pekerjaan, jenis kelamin, serta lama aktivitas senam jantung (Pre-Test dan Post-Test).

Analisis bivariat pada penelitian menunjukkan ada tidaknya dominasi variabel dependen dan variabel independen yang memakai Paired $T$ testbila data menunjukkan distribusi normal maka menggunakan Wilcoxon Signed Rank Testjika data dalam program SPSS tidak normal. bila $\mathrm{p} \leq$ 0,05 sehingga(Ho) ditolak $\operatorname{serta(Ha)}$ diterima, ini menyatakan bahwa terdapat pengaruh antara variabel independen dan dependen, sedangkan jika $\mathrm{p} \geq 0.05$ maka Ho diterima dan $\mathrm{Ha}$ ditolak, hal ini memperlihatkan tidak ada pengaruh terhadap variabel independendengandependen.Setelah itu nilai penelitian dilanjutkan dalam bentuk tabel dan dianalisis dengan teoriteori yang ada. 
Persiapaan alat-alat dan bahan yang dibutuhkan yaitu, air hangat 2 liter, baskom, handuk kecil dan garam 50 gram $(3,5 \mathrm{sdm})$. Prosedur pembuatan rendaman kaki dengan air garam hangat, yaitu siapkan garam 50 gram (3,5 sdm), kemudian tuang air hangat 2 liter ke dalam baskom yang sudah disiapkan. Masukkan garam di dalam baskom yang berisi air hangat, aduk sampai garam larut.
Prosedur pelaksanaan rendaman air garam hangat, yaitu inform consent, dianjurkan bersihkan kaki terlebih dahulu, kemudian rendam kaki ke air hangat yang sudah di tambahkan garam. Dapat di lakukan berdurasi 1020 menit, pastikan kaki terendam sampai batas mata kaki. Setelah selesai perendaman kaki, lap kaki dengan menggunakan handuk bersih dan lakukan hingga kering.

\section{HASIL}

Tabel 1.

Karakteristik Responden Berdasarkan Gender serta Usia ( $\mathrm{n}=20)$

\begin{tabular}{lcc}
\hline Karakteristik & f & $\%$ \\
\hline Gender & 8 & 40 \\
Laki-laki & 12 & 60 \\
Perempuan & & \\
\hline Usia & 10 & 50 \\
60-69 Tahun & 8 & 40 \\
70-79 Tahun & 2 & 10 \\
$\geq 80$ Tahun & & \\
\hline
\end{tabular}


Tabel 2.

Kualitas Tidur Sebelum Dilakukan Rendam Kaki di Air Garam Hangat (n=20)

\begin{tabular}{lcc}
\hline Kualitas Tidur & $\mathrm{f}$ & $\%$ \\
\hline Baik & 2 & 10 \\
Buruk & 18 & 90 \\
\hline
\end{tabular}

Tabel 3.

Kualitas Tidur Setelah Diberikan Rendam Kaki dengan Air Garam Hangat ( $\mathrm{n}=20)$

\begin{tabular}{lcc}
\hline Kualitas Tidur & $\mathrm{f}$ & $\%$ \\
\hline Baik & 16 & 80 \\
Buruk & 4 & 20 \\
\hline
\end{tabular}

Tabel 4.

Uji Normalitas Data Dan Responden Dengan Pengaruh Rendam Kaki Dengan Air Garam Hangat Dalam Peningkatan Kualitas Tidur Lansia.

\begin{tabular}{lcccc}
\hline Variabel & Shapiro-wilk & Variabel & Mean Rank & P-Value \\
\cline { 2 - 2 } & Sig & & & \\
\hline Pre Test & 0,000 & Skala Nyeri & 7,50 & 0,000 \\
Post Test & 0,000 & & 0,00 & \\
\hline
\end{tabular}

Tabel 1 menurut jenis kelamin di atas diperoleh laki-laki berjumlah 8 responden $(40 \%)$ serta perempuan 12 responden $\quad(60 \%)$. Berdasarkan karakteristik data usia diatas, didapatkan rentang usia 60-69 tahun yang berjumlah $10(50 \%)$ responden, 70-79 tahun sebanyak 8 (40\%) responden, $\geq 80$ tahun yang berjumlah 2 $(10 \%)$ responden.

Table 2 dapat peroleh data sebelum dilakukan tindakan perendaman kaki mayoritas kualitas tidur buruk dengan persentase $90 \%$ (18 orang) dan minoritas kualitas tidur baik dengan persentase $10 \%$ ( 2 orang).

Tabel 3 diperoleh data setelah dilakukan tindakan perendaman kaki mayoritas kualitas tidur baik dengan persentase $80 \%$ (16 orang) dan minoritas dengan kualitas tidur yang buruk dengan persentase $20 \%$ (4 orang).

\section{PEMBAHASAN}

Hasil penelitian mengenai pengaruh rendam kaki dengan air garam hangat dalam meningkatkn kualitas tidur dengan sampel berjumlah 20 responden. Kualitas tidur adalah waktu letensi tidur, frekuensi terbangun, lama tidur semalam, kepuasan tidur, kedalaman tidur, dan perasaan segar saat bangun pagi hari yang lebih banyak terjadi pada perempuan, dibandingkan dengan lakilaki. Disebabkan karena lansia dengan jenis kelamin perempuan lebih mudah mengalami stress, gelisah, dan cemas.

Tabel 1 distribusi responden menurut Gender dan Usia, mayoritas perempuan yang berjumlah 12 (60\%) serta minoritas laki-laki 8 orang $(40 \%)$ responden, menurut peneliti hal ini menyatakan bahwanya jenis kelamin perempuan lebih rentang dan beresiko menderita masalah kualitas tidur, dikarenakan adanya perubahanhormondi dalam tubuh, sertasuasana hati yang dapat berubah drastis setia psaat, simpulan ini sesuai 
dengan penelitian Endang Subandi (2017), dimana banyaknya jumlah lansia yang menderita dengan masalah gangguan tidur lebih cenderung beresiko kepada perempuan dari pada laki-laki.

Berdasarkan karakteristik umur, terdapat rentang umur 60-69 tahun berjumlah $10(50 \%)$ responden,70-79 tahun berjumlah $8(40 \%)$ responden, $\geq$ 80 tahun berjumlah $2(10 \%)$ responden, menurut peneliti hal ini menunjukan bahwa lansia mengalami masalah kualitas tidur, di mana pada saat sesorang memasuki masa lansia maka fungsi organ tubuh akan menurun di mana ketika seseorang memasuki usia lanjut maka fungsi organ akan mengalami penurunan di dalam tubuh serta menderita masalah dengan kualitas yang buruk hal ini menjadi satu faktor yang di alami pada usia lanjut, ini sama terjadi di penelitian yang di laksanakan Endang Subandi (2017) di mana faktor umur dapat mempengaruhi kualitas tidur.

Tabel 2 distribusi responden sebelum di lakukan rendam kaki dengan air garam hangat, data yang di peroleh sebagian besar memiliki kualitas tidur yang buruk, secara presentase 90\% (18 responden) dan Minoritas responden dengan kualitas tidur baik dengan persentase $10 \%$ ( 2 responden). menurut peneliti hal ini menyatakan bahwa sebelum di lakukan rendam kaki di air hangat garam, ini sama dengan peneliatian Endang Subandi (2017) tentang rendam kaki dengan air hangat dimana mayoritas responden sebelum di lakukan tindakan, memiliki kualitas tidur yang buruk.

Tabel 3 distribusi responden setelah di lakukan tindakan rendam kaki di air hangat garam, data yang di peroleh adanya peningkatan kualitas tidur dengan persentase $80 \%$ (16 responden) dan Minoritas responden dengan kualitas tidur buruk dengan persentase $20 \%$ (4 responden). menurut peneliti terjadi peningkatan yang di alami para usia lanjut terhadap kualitas tidurnya setelah di berikan tindakanperendam kaki denga air garam, ini di sebabkan karena air garam hangat mampu menggubah mikrosirkulasi pembulu darah dan vasodilatasi sehingga memberikan efek relaksasi yang mampu membatu lansia dalam menangani masalah kualitas tidur, ini sama penelitian yang di laksanakan Endang Subandi (2017) di mana dalam penelitian tersebut setelah di lakukan terapi merendam kaki di air hangat pasien mengalami peningkatan tidur yang semakin membaik.

Tabel 4 menunjukan hasil dari tes normalitas yang memakai cara normalitas Shapiro-wilk yaitu data distribusi responden di data pre-test mempunyai nilai sig $0,000<0,05$, jadi data tersebut tidak berdistribusi normal, sama halnya data post-test memiliki nilai sig $0,000<0,05$, dari itu data tersebut tidak berdistribusi normal dari hasil tes disimpulkan data berdistribusi tidak normal, makauntuk memahami data tersebut memakaites Wilcoxon Signed Rank Tes pada penelitian.

Beberapa cara dapat digunakan untuk menanggulangi masalah tidur, salah satunya dengan cara melakukan terapi rendam kaki yg termasuk dalam bentuk terapi relaksasi. Dengan menggunakan terapi rendam kaki dapat dimanfaatkan sebagai pemicu untuk memperbaiki ketahanan tubuh terhadap penyakit. Menurut uji Wilcoxon Signed Rank Tes hasil datadi gunakan ialah hasil penghitungan komponen kualitas tidur memakai kuesioner Pittsburgh Sleep 
Quality Index (PSQI) sebelum di lakukan penelitianpada hari pertama serta pengukuranhasil penghitungan komponen di akhir penelitian, nilai Mean Rank pretest-posttest sebesar7,500,00 jikap-value 0,000 .

Hasil perhitungan komponen di atas disimpulkan bahwa terdapat pengaruh merendamkan kaki dalam air garam hangat terhadap peningkatan kualitas tidur pada lansia, hal ini ditunjukan nilai sig $0,000<0,05$ bahwaHa di terima serta Ho ditolak. Hasil dalam penelitian ini sesuai dari hasil penelitian Endang Subandi (2017) dimana dalam penelitian tersebut dimuat terdapat pengaruh merendam kaki di air hangat bila nilai $p$-value 0,000 . Serta hasil penelitian Hardono, Elisa Oktaviana, Andoko (2019) menyatakan bahwa merendam kaki di air hangat merupakan terapi dapat mengatasi insomnia pada lanjut usia di mana dalam penelitian tersebut mengatakan bahwa ada pengaruh terapi air hangat dalam penurunan insomia denga nilai $p$-value 0,005 .

Terapi merendam kaki di air hangat dengan tambah garam menciptakan efek relaksasi bada tubuh. (Nuyridayanti, 2017). Toksin dalam tubuhakan di serapoleh panah dari garam yang dapat membuat sirkulasi darah menjadi lancar. (Dewi, dkk, 2020). Dari kondisi tubuh yang tenang dan relax merupakan Peningkatan dalam kualitas tidur,dimana kondisi tersebut mampu memudahkan seseorang untuk tidur menjadi nyaman, tenang, dan nyenyak (Endang Subandi, 2017). Setelah di berikan Rendaman Air Garam Hangat kepada responden mengalami Peningkatan dalam Kualitas Tidur, terapi rendam kaki di air garam hangat ialah hindro terapi yang baik yang berasal bahan alami serta tidak memiliki efek samping adanpekerjanya sangat mudah di lakuan.

\section{SIMPULAN}

Adanya peningkatan kualitas tidur sesudah dilaksanakan tindakan merendam kaki dalam air garam hangat pada lansia bertempat di Panti Jompo Yayasan Guna Budi Bakti Medan Tahun 2021.

\section{DAFTAR PUSTAKA}

Akbar Daniel W, Laila Purnamasari. (2019). Pengaruh Rendam Kaki Air Hangat Terhadap Kualitas Tidur Pada Lansia di Wilayah Kerja Puskesmas Handapherang.Tesediafile:///C:/U sers/ADMIN/Desktop/D3\%20LIT ERATUR/JURNALL/rendam\%20 kaki/2635- 8742-1-SM.pdf. diakses pada tanggal 3 Juni 2020 jam $16: 03$

Ananta Erfrandau, Murtaqib, Nur Widayati. (2017). Pengaruh Terapi Tawa terhadap Kualitas Tidur pada Lansia di Unit Pelayanan Teknis Panti Sosial Lanjut Usia (UPT PSLU) Kabupaten Jember (The Effect of Laughter Therapy on Sleep Quality of Elderly in Long-Term Care Jember). Pustaka Kesehatan

Chepi, L, Herliana \& W, Rivelino, S.H. (2018). Pengaruh Terapi Rendam Air Hangat Pada Kaki Terhadap Imsomnia Pada Lansia Di Kelurahan Angges Kecamatan Tahuna Barat. E-Journal Keperawatan (E-KP) Volume 6 Nomor 2:8.

Ifon, D.P. (2017). Pengaruh Rendam Air Hangat Pada Kaki Sebelum Tidur Terhadap Insomnia. Jurnal STIKes Payung Negeri Pekanbaru. 
Kementrian Kesehatan RI. (2013). Gambaran Kesehatan Lanjut Usia di Indonesia. Diunduh dari http://www.google.co.id pada tanggal 20 Desember 2017.

Kementerian Kesehatan RI. (2016). INFODATIN Pusat Data dan Informasi Kementerian Kesehatan RI Situasi Balita Pendek. Jakarta Selatan.

Kementrian Kesehatan RI. (2016). Gambaran Kesehatan Lanjut Usia di Indonesia. Diunduh dari http://www.google.co.id pada tanggal 22 Desember 2017.

Lendengtariang, C., Wungouw, H., \& Hamel, R.S. (2018). Pengaruh terapi rendam air hangat kaki terhadap insomnia pada lansia di Kelurahan Angges Kecamatan Tahuna Barat. e-journal Keperawatan (e-Kp), 6(2), 1-8.

Nuyridayanti, A. (2017). Pengaruh Rendam Air Garam Terhadap Penurunan Tingkat Nyeri Pada PenderitaGout Di Desa Toyoresmi Di Kecamatan Gampengrejo Kabupaten Kediri. Jurnal Kesehatan, 116-120.

Prananto, A.E. (2016). Pengaruh Masase Kaki Dan Rendam Air Hangat Pada Kaki Terhadap Penurunan Insomnia Pada Lansia.http://eprints.ums.ac.id/44 311/1
1/NASKAH\%20PUBLIKASI.p df. Diakases 19 Jul 2016 01:12.

Potter \& Perry. (2010). Fundamental Keperawatan Edisi 4 Volume 1. Jakarta : EGC

Rahayu Candra Dewi,dkk.(2020). Pengambilan Keputusan Klinis Perawat. Jurnal Kesehatan.

Ratnawati, Emmelia. (2017). Asuhan Keperawatan Gerontik.Yogyakarta:Penerbit Pustaka Baru Press.

Solechah, N., Masi, G. N. . and Rottie, J. V (2017) 'Pengaruh Terapi Rendam Kaki Dengan Air Hangat', Jurnal Keperawatan, 5(1), pp. 3-4. file:///D:/PUBLISH/JURNAL\%20 $\underline{\mathrm{AL}}$ \%20IRSYAD/reference/jurnal\%2 0Solechah\%20M,\%202017.pdf. diakses tanggal 22 Setember 2019

Wulandari, P. et al. (2016). Pengaruh Rendam Kaki Menggunakan Air Hangat dengan Campuran Garam dan Serai Terhadap Penurunan Tekanan Darah Pada Penderita Hipertensi di Wilayah Podorejo $R W \quad 8$ Ngaliyan. Keperawatan, 7(2009), 43-47.

http://ejournal.umm.ac.id/index.php/kep erawatan/article/viewFile/3918/43 97 